\title{
Donovanosis (granuloma inguinale) of the oral cavity
}

\author{
B. R. GARG, SARDARI LAL, AND B. M. S. BEDI \\ Department of Dermatology and Venereology \\ AND \\ D. V. RATNAM AND D. N. NAIK \\ Department of Dentistry, Fawaharlal Institute of Postgraduate Medical Education and Research, \\ Pondicherry, India
}

Extragenital granuloma inguinale in association with primary lesions in the genitalia, groin, or anal region has been reported by a number of workers (Sequiera, 1908; Hunter, 1923; Sidlik, 1927; Shropshear, 1938; Ayyangar, 1961), but there are very few case reports of primary oral donovanosis (Lal, Arunthathi, and Swahney, 1971).

Rajam and Rangiah (1954) in a series of 858 cases of donovanosis found two cases, and Ramachander, Jayalaxami, and Pankaja (1967) in a series of 867 cases found only one of primary oral donovanosis. Rao and Patnaik (1966), Bai, Sulibhavi, and Sundar (1969), and Bedi and Arunthathi (1972) in their series of 302,73, and 80 cases of donovanosis respectively did not report any as having oral lesions. It was therefore thought worth recording a further case of primary oral donovanosis.

\section{Case report}

A married 25-year-old female patient was referred from the Surgery Department for an opinion regarding oral ulceration. The ulcer had started about a year before as a red spot behind the last right upper molar tooth on the mucosa of the cheek. It gradually spread over the buccal surface of the right cheek and the palate and gums of the upper jaw, without giving her much discomfort except occasional bleeding while brushing the teeth.

Both the patient and her husband had had genital ulcers about 2 years before and had been treated by a local doctor. The husband had had oral coitus with her when she was pregnant $1 \frac{1}{2}$ years before.

\section{Examination}

There was circumscribed pink granulomatous ulceration involving the hard and soft palate, maxillary gingiva (Fig. 1), and mucosal surface of the right cheek. Palpation of the involved cheek did not reveal any induration or tenderness but caused bleeding. The rest of the oral mucosa including the tongue and tonsils was normal. Regional lymph nodes were not enlarged. The genitalia were normal. The husband had no lesions.

\section{Investigations}

Tissue smear from the ulcer margin showed macrophages with cytoplasmic encapsulated Donovan bodies (Fig. 2).

Received for publication June 10, 1974

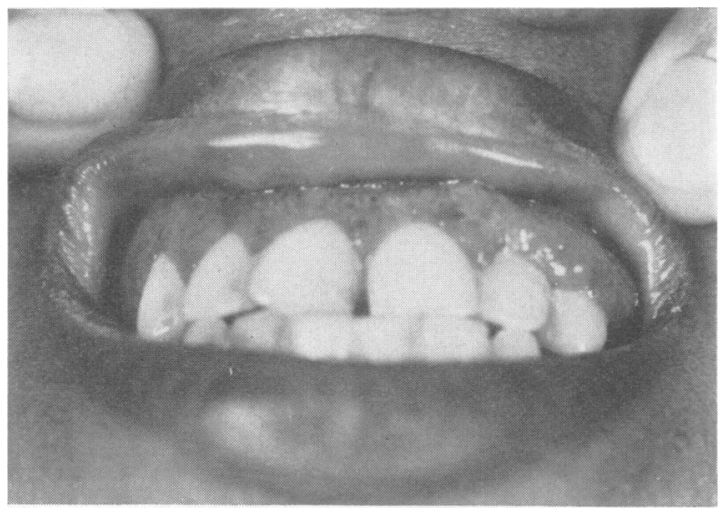

FIG. I Swollen congested labial maxillary gingiva with granulomatous ulceration

Blood VDRL test was non-reactive. Routine investigations of blood, urine, and stool were normal. Chest $x$ ray showed no abnormality.

Biopsy from the palate showed marked pseudoepitheliomatous hyperplasia and a very dense mononuclear cell infiltrate with foci of neutrophils in the dermis.

\section{Treatment and follow-up}

She was given oral tetracycline $500 \mathrm{mg}$. 6-hrly for 20 days. The ulcer healed and the gingivae (Fig. 3) became normal in 16 days. At follow-up 6 months later there was no evidence of recurrence.

\section{Comment}

Oral donovanosis was suspected in this case because of the chronic granulomatous ulceration, and the diagnosis was proved by the demonstration of Donovan bodies in the tissue smear. There are many causes of oral ulceration (Farmer and Lawton, 1966), but donovanosis of the oral cavity, being rare, is usually not thought of, with the result that the patient is shunted from one specialist to another before the proper diagnosis is made. When donovanosis affects the genitalia or neighbouring sites as well as the mouth, it is more likely to be considered. It should also be thought of in all cases of 
chronic ulceration in the mouth, especially when the diagnosis is obscure.

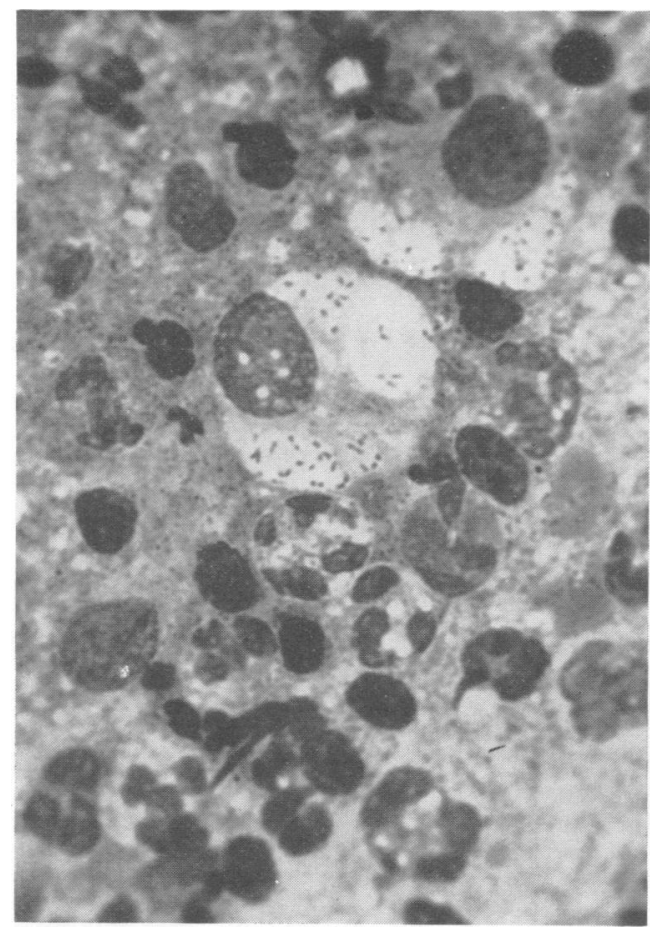

FIG. 2 Photomicrograph of tissue smear, showing macrophages with vacuolated cytoplasm containing encapsulated Donovan bodies (10 $\times$ 100)

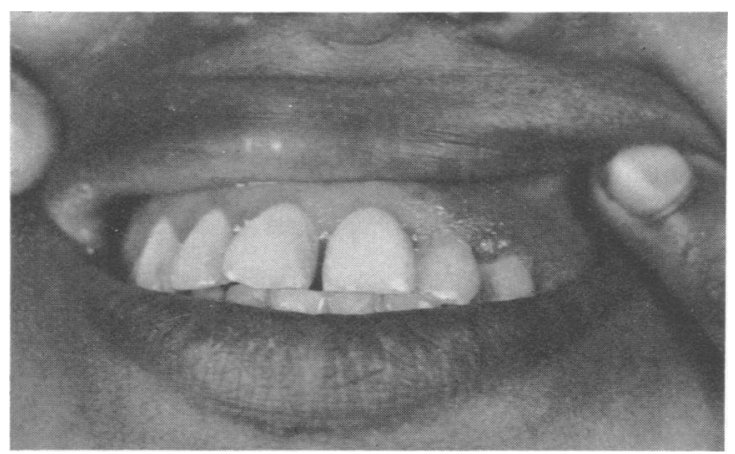

FI G. 3 Healed labial maxillary gingiva after treatment

\section{Summary}

A female patient suffering from donovanosis of the oral cavity without associated lesions elsewhere is reported. The importance of remembering donovanosis in the differential diagnosis of chronic granulomatous ulceration of the mouth is emphasized.

We are thankful to the Principal, Jawaharlal Institute of Postgraduate Medical Education and Research, Pondicherry-605006, for his kind permission to publish the case.

\section{References}

Ayyanger, M. C. R. (1961) f. Indian med. Ass., 37, 70

BaI, K. V., Sulibhavi, D. G., and Sundar, P. S. (1969) Indian f. Derm. Vener., 35, 45

Bedi, B. M. S., and ARUnthathi, S. (1972) Ibid., 38, 221

FARMeR, E. D., and Lawton, F. L. (eds) (1966) 'Stones' Oral and Dental Diseases', 5th ed., pp. 585-666. Livingstone, London

Hunter, R. S. (1923) Trans. Coll. Phycns Philad., 45, 455

Lal, S., Arunthathi, S., and Swahney, K. L. (1971) Indian f. Derm. Vener., 37, 19

Rajam, R. V., and RANGIAH, P. N. (1954) W.H.O. Series No. 24

RAmachander, K., JayalaXami, S., and PaNkaja,P.(1967) Indian F. Derm. Vener., 33, 237

RaO, N. V. S. R., and PatNaIK, R. (1966) Ibid., 32, 100

Sequiera, J. H. (1908) Proc. roy. Soc. Med., 1 (Sect. Derm.), p. 92.

Shropshear, G. (1938) Arch. Derm. Syph., 37, 926

SidLIK, D. M. (1927) Ibid., 15, 703

Donovanose (granulome inguinal) de la cavité buccale

\section{SOMMAIRE}

On rapporte le cas d'une femme atteinte de donovanose de la cavité buccale sans autre lésions associées. On souligne l'interêt de se rappeler la donovanose dans le diagnostic différentiel des ulcération granulomateuses chroniques de la bouche. 